\title{
MANAJEMEN KEUANGAN MADRASAH
}

\section{Fahrurrozi}

IAIN Walisongo Jln. Walisongo No. 35 Semarang Jawa Tengah 50185

Email: fahrur165@yahoo.com

\begin{abstract}
ABSTRAK
Penelitian ini bertujuan untuk mengetahui akuntabilitas pengelolaan dana pendidikan dan pembudayaan pengelolaan dana yang akuntabel untuk peningkatan mutu pendidikan di Madrasah Aliyah Pesantren Hidayatussubban Kota Semarang Jawa Tengah. Metode pengumpulan data yang digunakan adalah observasi dan studi dokumentasi. Teknik analisis data yang digunakan adalah analisis kritis. Berdasarkan metode tersebut, diperoleh temuan penelitian, yaitu pengelolaan dana pendidikan pada Madrasah Aliyah Pesantren Hidayatussubban Semarang, secara umum belum akuntabel. Hal tersebut ditandai dengan lemahnya sistem penyusunan RAPBS dan lemahnya sistem evaluasi atau pemeriksaan keuangan, sementara pelaksanaan keuangan pada madrasah tersebut cukup akuntabel. Oleh karena itu, untuk membudayakan pengelolaan dana pendidikan yang akuntabel, pihak madrasah harus mampu menegakkan sistem pengelolaan dana peningkatan mutu pendidikan yang akuntabel. Sistem pengelolaan dana yang akuntabel untuk meningkatkan mutu pendidikan terdiri atas input, proses, output, dan tujuan. Untuk menghantarkan pada tujuan pendidikan yaitu mutu, diperlukan standar input, standar proses, dan standar output.
\end{abstract}

Kata Kunci: Akuntabilitas, Pendidikan, Pembudayaan

\begin{abstract}
This research aims to recognize the accoutability of financial management of Madrasah Aliyah Pesantren in Semarang and the acculturation of acountable financial management to improve qualified education of Madrasah Aliyah at Pesantren Hidayatussubban in Semarang. The methods for collecting data consists of observation, and documents study. A critical analysis was used to analyze the data. Based on the method above, educational finance management of Madrasah Aliyah Pesantren Hidayatussubban in Semarang, is generally not accountable. It can be recognized from the weakness of budgetting system and the weakness of finance control, but the finance accounting of Madrasah Aliyah is sufficient enough. Therefore, to build the accountable culture of financial management, Madrasah Aliyah must establish financial management system for the development of education quality which consists of inputs, process, outputs, and objectives. To achieve this objectives, it needs some input standards, process standards, and output standards.
\end{abstract}

Keywords: Accountability, Education, Acculturation 


\section{PENDAHULUAN}

Terdapat dua agenda penting pemerintah berkenaan dengan bidang pendidikan, yaitu; peningkatan mutu Pendidikan Nasional dan pemerataan kesempatan memperoleh pendidikan bagi semua lapisan masyarakat Indonesia. Dalam rangka mewujudkan agenda tersebut, pemerintah melalui beberapa kebijakannya berupaya mewujudkan pendidikan yang berkualitas, di antaranya adalah kebijakan pendanaan untuk meningkatkan mutu pendidikan Indonesia. Dalam pasal 31 ayat (4) Undang-Undang Dasar Negara RI tahun 1945 dinyatakan "Negara memprioritaskan anggaran pendidikan sekurang-kurangnya 20 persen dari anggaran pendapatan dan belanja negara (APBN) serta anggaran pendapatan dan belanja daerah (APBD) untuk memenuhi kebutuhan penyelenggaraan pendidikan nasional".

Guna memenuhi tuntutan di atas, Pemerintah Pusat, Pemerintah Daerah, dan masyarakat Indonesia mengerahkan segenap sumber daya yang ada sesuai dengan peraturan perundang-undangan yang berlaku (pasal 47 ayat 2), termasuk sumber dana. Pengelolaan dana pendidikan hendaknya berdasarkan pada prinsip keadilan, efisiensi, transparansi, dan akuntabilitas publik. Hal ini didasarkan pada pasal 48 ayat 1 UUD RI 1945. Ketentuan undang-undang tersebut ditegaskan dalam Peraturan Pemerintah Nomor 48 Tahun 2008 bahwa sumber dana pendidikan itu berasal dari Pemerintah Pusat, Pemerintah Daerah, masyarakat dan bantuan pihak asing yang tidak mengikat.

Sosialisasi pendidikan bermutu dan merata yang dilakukan pemerintah melalui berbagai media televisi dan media cetak serta media lainnya, telah menumbuhkan kesadaran kritis berbagai kalangan masyarakat tentang pendanaan pendidikan. Dengan demikian, ketika terdapat sekolah/madrasah yang masih menarik pembayaran dari siswa, masyarakat secara kritis dapat mempertanyakan kebijakan sekolah/madrasah tersebut, sebab mereka mengetahui bahwa pemerintah telah memberikan bantuan dana pendidikan berupa BOS (Bantuan Operasional Sekolah) bahkan pemerintah telah mencanangkan pendidikan gratis untuk seluruh rakyat Indonesia.

Dalam praktiknya, pengelolaan pendanaan pendidikan di kota Semarang, seperti penggalangan dana yang dilakukan oleh kebanyakan sekolah/madrasah masih didominasi dari sumbangan orang tua/wali peserta didik, belum banyak mobilisasi atas sumber lain di luar orang tua siswa. Oleh karena keterbatasan kemampuan orang tua/wali murid dalam membiayai sekolah anaknya, maka kegiatan sekolah disesuaikan dengan dana yang tersedia. Sebagai respons atas fenomena tersebut, masyarakat menyoroti pemanfaatan dana yang dikaitkan dengan mutu pendidikan yang dicapai. Sebelum reformasi, masyarakat cenderung menerima apapun yang diberikan oleh pemangku pendidikan. Saat reformasi seperti sekarang ini, mereka tidak dengan mudah menerima hal-hal yang diberikan oleh penyelenggara pendidikan baik di madrasah maupun di sekolah. 
Secara kelembagaan, Madrasah Aliyah (MA) di kota Semarang dihadapkan kepada tantangan untuk memberikan jawaban tentang pemanfaatan dana yang diterima dan dikelola untuk penyelenggaraan pendidikan agar mampu menghasilkan output bermutu. Berkaitan dengan hal ini, muncul pertanyaan: "Bagaimana MA memanfaatkan dana pendidikan secara akuntabel, sehingga dapat menghasilkan mutu pendidikan sesuai dengan tuntutan stakeholders"? Pertanyaan ini penting untuk dijawab dan dijelaskan oleh MA melalui mekanisme penyelenggaraan pendidikan secara bertanggung jawab dan bermutu, sehingga masyarakat atau pihak yang berkepentingan puas dan tidak curiga bahwa selama ini MA hanya sekedar menghabiskan dana pemerintah dan masyarakat.

Studi tentang akuntabilitas pengelolaan dana untuk peningkatan mutu pendidikan, khususnya Madrasah Aliyah yang berbasis pesantren menjadi sangat penting dan aktual manakala dikaitkan dengan terbatasnya sumber dana yang tersedia serta rendahnya kekuatan ekonomi pemerintah dan masyarakat untuk membiayai pendidikan. Kecenderungan ini menuntut adanya kemampuan pengelolaan dana pendidikan secara akuntabel yang diwujudkan dalam pertanggungjawaban keberhasilan pencapaian mutu pendidikan.

Penelitian ini bertujuan untuk mengetahui akuntabilitas pengelolaan dana dalam rangka meningkatkan mutu pendidikan Madrasah Aliyah Pesantren Hidayatussubban kota Semarang dan mengetahui aspek-aspek yang perlu dikembangkan dan dibudayakan untuk mewujudkan pengelolaan dana pendidikan yang akuntabel, sehingga pada gilirannya mutu pendidikan Madrasah Aliyah berbasis pesantren di kota Semarang dapat ditingkatkan.

\section{PEMBAHASAN}

\section{Akuntabilitas}

Deklarasi Tokyo menetapkan pengertian akuntabilitas yakni kewajibankewajiban individu atau penguasa yang dipercayakan untuk mengelola sumbersumber daya publik sehingga dapat menjawab hal-hal yang menyangkut pertanggungjawaban fiskal, manajerial, dan program (www.pekalongankab.go.id. Diakses tanggal 31-12-2008). Slamet (2005: 5) menyebutkan akuntabilitas adalah kewajiban untuk memberikan pertanggungjawaban atau untuk menjawab dan menerangkan kinerja dan tindakan penyelenggara organisasi kepada pihak yang memiliki hak atau kewajiban untuk meminta keterangan atau pertanggungjawaban. Zamroni mendefinisikan akuntabilias yaitu:

".....is the degree to which local governments have to explain or justify what they have done or failed to do. Accountability can be seen as validation of participation, in that the test of whether attempts to increase participation prove successful is the extent to which people can use participation to hold a local government responsible for its action" (Zamroni, 2008: 12). 
Pendapat Zamroni mengenai akuntabilitas di atas berkaitan dengan partisipasi. Ini berarti, akuntabilitas hanya dapat terjadi jika ada partisipasi dari stakeholders sekolah. Semakin kecil partisipasi stakeholders dalam penyelenggaraan manajemen sekolah, semakin rendah pula akuntabilitas sekolah.

Menurut Saleh dan Aslam Iqbal (1999: 19), akuntabilitas dapat dibagi ke dalam dua jenis, yaitu akuntabilitas intern (internal accountability) dan akuntabilitas ekstern (external accountability). Internal accountability to the public servant own organization. Setiap tingkatan pada hirarki organisasi, petugas pelayanan publik diwajibkan untuk berlaku akuntabel kepada atasannya dan kepada yang mengontrol pekerjaannya. Akuntabilitas internal memerlukan komitmen dari seluruh petugas untuk memenuhi kriteria pengetahuan dan keahlian dalam melaksanakan tugas-tugasnya sesuai dengan posisinya, external accountability to the individual and organization out side public servant's own organization, yakni kemampuan untuk menjawab setiap pertanyaan yang berhubungan dengan pencapaian kinerja pelaksanaan tugas dan wewenang. Untuk itu, selain kebutuhan dan keahlian seperti yang disebutkan sebelumnya, juga dibutuhkan komitmen untuk melaksanakan kebijakan dan program-program yang telah dijanjikan/ dipersyaratkan sebelum dia memangku jabatan.

Menurut pelaksanaan kegiatannya, akuntabilitas dapat dikelompokan menjadi: (a) akuntabilitas keuangan; (b) akuntabilitas manfaat; dan (c) akuntabilitas prosedural (Lembaga Administrasi Negara, 2000). Akuntabilitas keuangan merupakan pertanggungjawaban mengenai integritas keuangan, pengungkapan, dan ketaatan terhadap peraturan perundangan. Sasaran pertanggungjawaban adalah laporan keuangan yang disajikan sesuai peraturan perundangan yang berlaku, yang mencakup penerimaan, penyimpanan, dan pengeluaran uang oleh instansi pemerintah.

Akuntabilitas manfaat 'keefektivan' memberi perhatian kepada hasil dari kegiatan. Pertanggungjawaban terhadap kepatuhan kepada aturan, serta keefektivan yang dicapai selain output-nya optimal, juga mengandung manfaat (outcome) yang signifikan terhadap tujuan yang telah ditetapkan. Akuntabilitas prosedural, yaitu pertanggungjawaban mengenai apakah suatu prosedur penetapan dan pelaksanaan suatu kebijakan telah mempertimbangkan masalah moral, etika, kepastian hukum, dan ketaatan kepada keputusan politis untuk mendukung pencapaian tujuan akhir yang telah ditetapkan seperti halnya yang dilakukan pada akuntabilitas proses.

Tujuan akuntabilitas adalah agar terciptanya kepercayaan publik terhadap sekolah. Kepercayaan publik yang tinggi terhadap sekolah dapat mendorong partisipasi yang lebih tinggi terhadap pengelolaan manajemen sekolah. Sekolah akan dianggap sebagai agen bahkan sumber perubahan masyarakat. Pelaksanaan prinsip akuntabilitas dalam rangka MBS (Manajemen Berbasis Sekolah) bertujuan agar para pengelola sekolah atau pihak-pihak yang diberi kewenangan mengelola urusan pendidikan itu senantiasa terkontrol dan tidak memiliki peluang melakukan penyimpangan untuk melakukan korupsi, kolusi, dan 
nepotisme. Dengan prinsip ini, mereka terus memacu produktivitas profesionalitasnya sehingga berperan besar dalam memenuhi berbagai aspek kepentingan masyarakat.

Dalam konteks kebijakan pemerintah melalui Permendiknas no. 19 tahun 2007 tentang Standar Pengelolaan Pendidikan dinyatakan bahwa dalam pengelolaan keuangan sekolah/madrasah terdapat beberapa ketentuan, yaitu:

a. Sekolah/madrasah menyusun pedoman pengelolaan biaya investasi dan operasional yang mengacu pada standar pembiayaan;

b. Pedoman pengelolaan biaya investasi dan operasional sekolah/madrasah mengatur:

1) Sumber pemasukan, pengeluaran, dan jumlah dana yang dikelola;

2) penyusunan dan pencairan anggaran, serta penggalangan dana di luar dana investasi dan operasional;

3) Kewenangan dan tanggungjawab kepala sekolah/madrasah dalam membelanjakan anggaran pendidikan sesuai dengan peruntukannya;

4) Pembukuan semua penerimaan dan pengeluaran serta penggunaan anggaran, untuk dilaporkan kepada komite sekolah/madrasah, serta institusi di atasnya.

c. Pedoman pengelolaan biaya investasi dan operasional sekolah/madrasah diputuskan oleh komite sekolah/madrasah dan ditetapkan oleh kepala sekolah/madrasah serta mendapatkan persetujuan dari institusi di atasnya;

d. Pedoman pengelolaan biaya investasi dan operasional sekolah/madrasah disosialisasikan kepada seluruh warga sekolah/madrasah untuk menjamin tercapainya pengelolaan dana secara transparan dan akuntabel.

Akuntabilitas akan semakin memiliki arti ketika sekolah mampu mempertanggungjawabkan mutu output-nya terhadap publik. Sekolah yang mampu mempertanggungjawabkan kualitas output-nya terhadap publik, mencerminkan sekolah yang memiliki tingkat keefektivan yang tinggi terhadap output. Sekolah yang memiliki tingkat keefektivan output tinggi, akan meningkatkan efisiensi eksternal.

\section{Pengelolaan Dana Pendidikan}

Perhitungan biaya pendidikan sangat ditentukan oleh komponen kegiatan pendidikan dan biaya satuan. Komponen kegiatan pendidikan meliputi pengadaan sarana dan prasarana pendidikan seperti; ruang belajar, ruang laboratorium, ruang perpustakaan, alat pelajaran, dan alat olah raga, buku pelajaran/kepustakaan lain, perabot sekolah, perlengkapan sekolah, dan alat tulis-menulis. Proses belajar-mengajar, gaji guru/pendidik dan gaji bukan guru/tenaga kependidikan termasuk dalam komponen kegiatan pendidikan (Biro Perencanaan P\&K, 1989: 12). Oleh karena itu, di dalam analisis biaya, 
komponen ini harus dirinci sampai pada kegiatan yang terkecil untuk dapat ditentukan jumlah dan biaya satuannya.

Berhubungan dengan biaya yang harus dikeluarkan untuk memenuhi kebutuhan pendidikan, terdapat beberapa pengertian dasar atau konsep dasar tentang pengeluaran biaya, yaitu;

a. Biaya langsung 'direct cost' dan biaya tidak langsung 'indirect cost'. Biaya langsung adalah segala pengeluaran yang secara langsung menunjang penyelenggaraan pendidikan. Biaya tidak langsung adalah pengeluaran yang tidak secara langsung menunjang proses pendidikan tetapi memungkinkan membantu menyukseskan proses pendidikan yang terjadi di sekolah, misalnya biaya hidup siswa, biaya transportasi ke sekolah, biaya jajan, biaya kesehatan, dan harga kesempatan 'opportunity cost' (Anwar, M.I., 1991: 56-60).

b. Biaya pribadi 'private cost' dan biaya sosial 'social cost'. Biaya pribadi adalah biaya pendidikan yang harus dikeluarkan oleh masing-masing individu atau masyarakat untuk mendapatkan pendidikan. Biaya sosial atau dikenal juga dengan public cost adalah mencakup biaya-biaya yang didanai melalui pajak yang dihimpun oleh pemerintah kemudian digunakan untuk membiayai pendidikan (Jones, 1985: 5).

c. Biaya tetap 'fixed cost' dan biaya variabel 'variable cost'. Biaya tetap merupakan biaya yang dikeluarkan untuk pengadaan barang-barang modal seperti gedung sekolah, peralatan sekolah, sewa tahunan, dan gaji kepala sekolah. Adapun biaya tidak tetap merupakan biaya yang dikeluarkan untuk membiayai peralatan operasional ruang kelas, seperti buku pelajaran, gaji guru/pendidik dan nonguru/tenaga kependidikan (Biro Perencanaan P\&K, 1989: 12).

Dalam konteks ke-Indonesia-an, berhubungan dengan alokasi biaya pendidikan tersebut, pemerintah melalui Peraturan Pemerintah No. 48 Tahun 2008 menyatakan bahwa biaya pendidikan meliputi biaya satuan pendidikan; biaya penyelenggaraan dan/atau pengelolaan pendidikan; dan biaya pribadi peserta didik. Biaya satuan pendidikan mencakup biaya investasi (lahan dan selain lahan pendidikan), biaya operasional (personalia dan nonpersonalia), bantuan biaya pendidikan, dan beasiswa. Biaya penyelenggaraan pendidikan mencakup biaya alat dan perlengkapan pembelajaran (alat tulis, tempat duduk, buku pelajaran, alat peraga dan perlengkapan laboratorium).

Pengelolaan biaya pendidikan merupakan aplikasi dari manajemen fungsifungsi keuangan terhadap pendidikan. Fungsi keuangan merupakan kegiatan utama yang harus dilakukan oleh mereka yang bertanggung jawab dalam bidang tertentu. Jika ekonomi berfokus pada alokasi dan pembiayaan berfokus pada distribusi, maka, pengelolaan biaya berfokus pada fungsi-fungsi manajemen atau pelaksanaan.

Pengelolaan biaya pendidikan memiliki tiga tahap penting, yaitu: perencanaan, implementasi, dan evaluasi. Perencanaan mencakup pengaturan 
secara kordinatif terhadap sumber-sumber daya manusia dan material untuk mencapai sasaran yang diinginkan secara sistematis tanpa menimbulkan pengaruh negatif. Implementasi merupakan tindakan lanjutan dari rencana yang dilakukan secara bertahap dan disesuaikan dengan kebutuhan. Evaluasi merupakan tahap penentuan bahwa sasaran yang direncanakan betul-betul telah tercapai. Ketiga tahap tersebut ketika diterapkan dalam manajemen keuangan pendidikan menjadi tahap perencanaan keuangan (budgeting), tahap pelaksanaan keuangan (accounting), dan tahap penilaian atau evaluasi keuangan (auditing) (Jones, 1985: 5; Halim, 2006: 41; dan Bastian, 2006: 58-60).

\section{Mutu Pendidikan}

Sesuatu yang bermutu merupakan bagian dari standar yang sangat tinggi yang tidak dapat diungguli oleh produk lain. Produk-produk yang bermutu adalah sesuatu yang dibuat dengan sempurna dan dengan biaya yang cukup mahal. Mutu dalam pengertian ini dapat disebut dengan bigh quality atau top quality (Sallis, 1993: 51). Ketika dihubungkan dengan konteks pendidikan, konsep mutu terkesan elitis, karena hanya sedikit saja institusi pendidikan yang dapat memberikan pengalaman pendidikan bermutu tinggi 'bigh quality' kepada peserta didik. Kebanyakan, peserta didik tidak bisa menjangkaunya, dan sebagian besar institusi pendidikan tidak mampu memenuhinya. Dalam arti ini, mutu pendidikan lebih bermakna normatif-absolut.

Mutu dapat juga digunakan sebagai suatu konsep yang objektif-relatif. Pengertian ini digunakan dalam TQM (Total Quality Management). Definisi relatif dalam memandang mutu tersebut, tidak sebagai suatu atribut poduk atau servis (jasa), tetapi sebagai sesuatu yang dianggap berasal dari produk atau servis tersebut. Mutu dapat dikatakan ada apabila sesuatu yang baik atau servis memenuhi spesifikasi yang ada. Mutu tidak berakhir di dalam dirinya, tetapi ia merupakan suatu makna yang dengan produk terakhir itulah ia dinilai agar standarnya naik. Produk atau servis mutu, dalam konsep relatif ini tidak harus mahal dan eksklusif. Produk atau servis tersebut tidak harus spesial, tetapi ia harus asli, lumrah, dan familiar. Overhead projector, pena ballpoint, dan servis catering sekolah bisa dikatakan bermutu jika sederhana tapi memenuhi standar. Mereka harus mengerjakan hal-hal yang seharusnya dikerjakan, dan mengerjakan hal-hal yang diinginkan pelanggan. Dengan perkataan lain, ia harus sesuai dengan tujuannya.

Definisi relatif tentang mutu tersebut mempunyai dua aspek. Pertama, ia memiliki spesifikasi yang dikehendaki (measuring up), dan kedua, memenuhi kebutuhan pelanggan. Cara pertama, -measuring up- sering disimpulkan sebagai fitnees for purpose or use (kesesuaian dengan tujuan dan manfaat). Kadang-kadang, ini dinamakan definisi produsen tentang mutu. Mutu bagi produsen diperoleh dengan produk atau lanyanan yang memenuhi spesifikasi sebagaimana yang telah ditetapkan sebelumnya, dalam suatu bentuk atau mode yang konsisten. Mutu dapat diwujudkan oleh seorang produsen yang mempunyai sistem mutu (quality 
assurance system), yaitu suatu sistem yang mensyaratkan adanya produksi yang konsisten terhadap nilai standar atau spesifikasi khusus yang baik. Sebuah produk dikatakan bermutu jika secara konsisten sesuai dengan tuntutan mutu pembuatnya (Sallis, 1993: 51).

Organisasi yang menganut konsep TQM melihat mutu sebagai sesuatu yang didefinisikan oleh pelanggan mereka. Pelanggan adalah penentu akhir mutu, dan tanpa mutu, institusi tidak akan eksis. Institusi TQM harus menggunakan pemaknaan ini untuk mengeksplorasi keperluan pelanggannya. Mutu dapat didefinisikan sebagai sesuatu yang memuaskan dan melampaui keinginan dan kebutuhan pelanggan. Para pelangganlah yang membuat keputusan terhadap mutu, karena mereka berperan sebagai pelaku 'performer' dan pembanding yang baik.

Dalam konteks Pendidikan Nasional, dan dalam hubungannya dengan standar mutu pendidikan, pemerintah telah mengeluarkan kebijakan melalui Peraturan Menteri Pendidikan Nasional (Permendiknas) tentang Standar Nasional Pendidikan (SNP). Permendiknas tersebut berisi penegasan bahwa kebermutuan sebuah pendidikan dapat diukur melalui kemampuan masingmasing satuan pendidikan dalam memenuhi standar nasional pendidikan, yang terdiri atas:

a. Standar pengelolaan pendidikan adalah standar pengelolaan pendidikan untuk sekolah/madrasah yang berkaitan dengan perencanaan, pelaksanaan, dan pengawasan kegiatan pendidikan agar tercapai efisiensi dan keefektivan penyelenggaraan pendidikan.

b. Standar kompetensi lulusan adalah kualifikasi kemampuan lulusan yang mencakup sikap, pengetahuan, dan keterampilan. Standar ini disusun dan dikembangkan oleh Badan Standar Nasional Pendidikan (BSNP) yang ditetapkan oleh Keputusan Menteri Pendidikan Nasional.

c. Standar isi adalah ruang lingkup materi dan tingkat kompetensi yang dituangkan dalam kriteria tentang kompetensi tamatan, kompetensi bahan kajian, kompetensi mata pelajaran, dan silabus pembelajaran yang harus dipenuhi oleh peserta didik pada jenjang dan jenis pendidikan tertentu. Standar ini disusun dan dikembangkan oleh BSNP dan ditetapkan oleh Keputusan Menteri Pendidikan Nasional.

d. Standar proses adalah standar nasional pendidikan yang berkaitan dengan pelaksanaan pembelajaran pada satu satuan pendidikan untuk mencapai standar kompetensi lulusan. Standar ini disusun dan dikembangkan oleh BSNP dan ditetapkan oleh Keputusan Menteri Pendidikan Nasional.

e. Standar pendidik dan tenaga kependidikan adalah kriteria pendidikan prajabatan dan kelayakan fisik maupun mental, serta pendidikan dalam jabatan. Standar ini disusun dan dikembangkan oleh BSNP dan ditetapkan oleh Keputusan Menteri Pendidikan Nasional. 
f. Standar sarana dan prasarana adalah standar nasional pendidikan yang berkaitan dengan kriteria minimal tentang ruang belajar, tempat berolahraga, tempat beribadah, perpustakaan, laboratorium, bengkel kerja, tempat bermain, tempat berkreasi dan berekreasi, serta sumber belajar lain, yang diperlukan untuk menunjang proses pembelajaran, termasuk penggunaan teknologi informasi dan komunikasi. Standar ini disusun dan dikembangkan oleh BSNP dan ditetapkan oleh Keputusan Menteri Pendidikan Nasional.

g. Standar pembiayaan adalah standar yang mengatur komponen dan besarnya biaya operasi satuan pendidikan yang berlaku selama satu tahun. Standar ini disusun dan dikembangkan oleh BSNP dan ditetapkan oleh Keputusan Menteri Pendidikan Nasional.

h. Standar penilaian pendidikan adalah standar nasional pendidikan yang berkaitan dengan mekanisme, prosedur, dan instrumen penilaian hasil belajar peserta didik. Standar ini disusun dan dikembangkan oleh BSNP dan ditetapkan oleh Keputusan Menteri Pendidikan Nasional. (Permendiknas No. 17 dan 19 Tahun 2007).

Penelitian dilakukan terhadap Madrasah Aliyah Pesantren Hidayatussubban kota Semarang (Semarang Timur). Guna memperoleh data yang holistik dan integratif, serta memperhatikan relevansi dengan fokus dan tujuan, maka pengumpulan data menggunakan tiga teknik utama, yaitu: 1) wawancara mendalam (indepth interview), 2) observasi, dan 3) studi dokumentasi. Tiga teknik tersebut merupakan teknik dasar dalam penelitian kualitatif yang disepakati oleh sebagian besar peneliti (Creswell, 2008: 214). Wawancara dilakukan kepada Ketua Yayasan, Kepala Sekolah, dan guru Madrasah Aliyah Pesantren Hidayatussubban Kota Semarang. Tujuannya, untuk menggali datadata tentang proses perencanaan, pelaksanaan, dan evaluasi pemanfaatan dana pendidikan Madrasah. Observasi dilakukan untuk memperoleh data pelaksanaan pemanfaatan dana pendidikan Madrasah Aliyah Hidayatussubban dengan menghadiri rapat pengendalian program. Untuk memperkuat data-data hasil wawancara dan observasi, / ditelaah dokumen-dokumen yang tersedia berkaitan dengan perencanaan, pelaksanaan, dan pengendalian pemanfaatan dana pendidikan pada Madrasah Aliyah Pesantren Hidayatussubban Kota Semarang.

Data tersebut dianalisis dengan menggunakan analisis siklus. Menurut Huberman dan Milles, dalam pengumpulan data yang terekam melalui berbagai macam cara, baik wawancara, intisari dokumen, rekaman atau observasi lainnya diproses lebih lanjut dalam bentuk catatan. Model ini terdiri atas tiga alur kegiatan yang terjadi secara bersamaan yaitu mulai dari waktu mengumpulkan data, reduksi data, penyajian data, dan penarikan kesimpulan (Huberman dan Milles, 1984: 429).

Dalam penelitian ini, reduksi data dilakukan dengan melakukan pemilihan, pengurangan, penyederhanaan, dan pentransformasian data kasar yang muncul 
dari catatan tertulis di lapangan tentang akuntabilitas pengelolaan dana. Reduksi ini dilakukan untuk menentukan jenis data yang akan diambil dan dipakai serta jenis data yang tidak dipakai. Setelah reduksi data dilakukan, tahap berikutnya adalah penyajian data tentang akuntabilitas pengelolaan dana yang diperoleh secara sistematik, penuh kepedulian, kreativitas dan usaha tanpa henti sampai berhasil menarik simpulan dan pemaknaannya. Selanjutnya, dilakukan penarikan simpulan yang diwujudkan dengan cara menegaskan dan memaparkan secara singkat dan jelas tentang hal-hal yang dipaparkan dalam proses penyampaian data tentang akuntabilitas pengelolaan dana, sekaligus karakteristik yang menonjol dalam pengelolaan dana tersebut.

\section{Akuntabilitas Pengelolaan Dana Pendidikan di MA Pesantren}

Terdapat tiga hal penting yang menjadi fokus akuntabilitas pengelolaan dana pendidikan pada Madrasah Aliyah Pesantren Hidayatussubban Kota Semarang, yaitu akuntabilitas penyusunan Rencana Anggaran Pendapatan dan Belanja Sekolah (RAPBS), akuntabilitas pelaksanaan, dan akuntabilitas evaluasi.

Akuntabilitas penyusunan RAPBS pada Madrasah Aliyah Pesantren Hidayatussubban Kota Semarang, dapat diketahui dari enam faktor, yakni: 1) penyusunan RAPBS dilakukan oleh tim, 2) rapat tim yang dihadiri oleh semua unsur, 3) penyusunan RAPBS didasarkan pada analisis kebutuhan, 4) penentuan skala prioritas yang berorientasi pada mutu, 5) sumber-sumber dana yang variatif, 6) alokasi anggaran untuk peningkatan mutu pendidikan.

Berdasarkan enam faktor di atas, dapat diketahui bahwa akuntabilitas penyusunan RAPBS di MA Hidayatussubban Kota Semarang, secara ringkas, dapat digambarkan melalui tabel sebagai berikut.

\begin{tabular}{|c|l|c|c|}
\hline No & \multicolumn{1}{|c|}{ Uraian } & $\begin{array}{c}\text { Tidak } \\
\text { Ada }\end{array}$ & Ada \\
\hline 1 & Penyusunan RAPBS dilakukan oleh tim & $\checkmark$ & \\
\hline 2 & Rapat tim yang dihadiri oleh semua unsur & $\checkmark$ & \\
\hline 3 & Penyusunan RAPBS didasarkan pada analisis kebutuhan & & $\checkmark$ \\
\hline 4 & Penentuan skala prioritas yang berorientasi pada mutu & $\checkmark$ & \\
\hline 5 & Sumber-sumber dana yang variatif & & $\checkmark$ \\
\hline 6 & Alokasi anggaran untuk peningkatan mutu pendidikan: & & \\
\hline & a. Untuk pencapaian standar pengelolaan & $\checkmark$ & \\
\hline & b. Untuk pencapaian standar kompetensi lulusan & $\checkmark$ & \\
\hline & c. Untuk pencapaian standar isi & $\checkmark$ & \\
\hline & d. Untuk pencapaian standar proses & $\checkmark$ & \\
\hline & e. Untuk pencapaian standar tenaga pendidik \& kependidikan & & $\checkmark$ \\
\hline & f. $\quad$ Untuk pencapaian standar sarana prasarana & & $\checkmark$ \\
\hline & g. Untuk pencapaian standar pembiayaan & $\checkmark$ & \\
\hline & h. Untuk pencapaian standar penilaian & $\checkmark$ & \\
\hline
\end{tabular}

Berdasarkan tabel di atas, dapat diketahui bahwa penyusunan RAPBS pada Madrasah Aliyah Pesantren Hidayatussubban Semarang cenderung belum akuntabel. Dari segi pelaksanaan, akuntabilitas pengeluaran keuangan dapat 
diketahui melalui enam indikator, yaitu: 1) APBS disosialisasikan kepada warga sekolah, 2) pelaksanaan APBS sesuai dengan yang direncanakan, 3) ada buku kontrol pemasukan, 4) ada buku kas/pembukuan keuangan, 5) SPJ dilengkapi dengan bukti-bukti yang sah, dan 6) ada berita acara pemeriksaan administrasi keuangan. Berdasarkan enam faktor di atas, dapat diketahui bahwa akuntabilitas penyusunan pelaksanaan APBS MA Pesantren Semarang, secara ringkas, dapat dijelaskan melalui tabel sebagai berikut.

\begin{tabular}{|c|l|c|c|}
\hline No. & \multicolumn{1}{|c|}{ Uraian } & $\begin{array}{c}\text { Tidak } \\
\text { Ada }\end{array}$ & Ada \\
\hline 1 & Sosialisasi APBS & $\checkmark$ & \\
\hline 2 & Kesesuaian Pelaksanan dengan RAPBS & $\checkmark$ & $\checkmark$ \\
\hline 3 & Buku kontrol pemasukan & & $\checkmark$ \\
\hline 4 & Buku kas/pembukuan keuangan & & $\checkmark$ \\
\hline 5 & SPJ dilengkapi dengan bukti-bukti yang sah & & $\checkmark$ \\
\hline 6 & Berita acara pemeriksaan administrasi keuangan & & $\checkmark$ \\
\hline
\end{tabular}

Berdasarkan tabel di atas, dapat diketahui bahwa pelaksanaan pengeluaran biaya pendidikan di Madrasah Hidayatussubban Semarang, cukup akuntabel. Sedangkan dari segi evaluasi, akuntabilitas pengelolaan dana dapat diketahui melalui faktor berikut: 1) pengelolaan keuangan dilaporkan kepada pihak yayasan, pemerintah, guru, komite, dan wali siswa secara periodik; 2) pertanggungjawaban keuangan sekolah dilaporkan secara terbuka dalam rapat pleno komite.

Berdasarkan faktor-faktor di atas, dapat diketahui bahwa akuntabilitas penyusunan pelaksanaan APBS MA Pesantren Hidayatussubban Kota Semarang, secara ringkas, dapat dijelaskan melalui tabel sebagai berikut.

\begin{tabular}{|c|l|c|c|}
\hline No. & \multicolumn{1}{|c|}{ Uraian } & $\begin{array}{c}\text { Tidak } \\
\text { Ada }\end{array}$ & Ada \\
\hline 1 & Pelaporan pengelolaan keuangan pada: & & \\
\hline & a. Pemerintah & & $\checkmark$ \\
\hline & b. Yayasan & $\checkmark$ & $\checkmark$ \\
\hline & c. Komite & $\checkmark$ & \\
\hline & d. Guru & $\checkmark$ & \\
\hline 2 & $\begin{array}{l}\text { Pelaporan pertanggungjawaban keuangan dalam } \\
\text { rapat pleno }\end{array}$ & $\checkmark$ & \\
\hline
\end{tabular}

Berdasarkan penjelasan di atas, dapat diketahui bahwa evaluasi pengelolaan keuangan pada Madrasah Aliyah Pesantren Hidayatussubban Semarang cenderung belum akuntabel. 


\section{Pembudayaan Akuntabilitas Pengelolaan Dana untuk Peningkatan Mutu}

Sebagaimana ditegaskan dalam uraian sebelumnya, akuntabilitas dipahami sebagai suatu upaya mempertanggungjawabkan segala bentuk kegiatan pengelolaan dana keuangan yang dilakukan secara proaktif oleh pihak madrasah. Adapun media penyampaian laporan pertanggungjawaban tidak terbatas dalam bentuk laporan lisan maupun dalam bentuk laporan tertulis, namun mencakup juga akses dan kemudahan mendapatkan informasi tentang suatu kegiatan baik langsung maupun tidak langsung, lisan maupun tulisan.

Tujuan akuntabilitas pengelolaan dana pendidikan adalah agar terciptanya kepercayaan publik terhadap sekolah/madrasah dan mendorong terciptanya akuntabilitas kinerja sekolah/madrasah sebagai salah satu syarat untuk terciptanya sekolah yang baik dan terpercaya dalam rangka meningkatkan mutu pembelajaran di sekolah/madrasah.

Berdasarkan data akuntabilitas pengelolaan dana pada tabel-tabel di atas, diketahui bahwa pada proses penyusunan RAPBS dan evaluasi Madrasah Aliyah Pesantren Hidayatussubban Kota Semarang dapat dikatakan kurang akuntabel. Pada tahap pelaksanaan Madrasah Aliyah Pesantren Kota Semarang cukup akuntabel. Jika melihat kecenderungan umum pada tabel di atas maka dapat diasumsikan bahwa pengelolaan dana pendidikan pada Madrasah Aliyah Pesantren Hidayatussubban secara umum dapat dikatakan belum akuntabel. Hal tersebut dapat dilihat, bahwa lebih dari 50\% indikator pengelolaan dana yang akuntabel tidak terpenuhi.

Penegakan akuntabilitas pengelolaan dana pendidikan secara keseluruhan sangat penting bagi madrasah. Sebagaimana dijelaskan sebelumnya untuk mewujudkan madrasah yang akuntabel, pemerintah melalui Permendiknas no. 19 tahun 2007 tentang Standar Pengelolaan Pendidikan, menegaskan bahwa dalam pengelolaan keuangan sekolah/madrasah terdapat beberapa ketentuan, yang salah satunya adalah bahwa pedoman pengelolaan biaya investasi dan operasional sekolah/madrasah disosialisasikan kepada seluruh warga sekolah/madrasah untuk menjamin tercapainya pengelolaan dana secara transparan dan akuntabel.

Merespons kondisi obyektif Madrasah Aliyah Pesantren tersebut, Codd menyatakan bahwa ada dua jenis akuntabilitas, yaitu akuntabilitas eksternal dan akuntabilitas internal. Keduanya memiliki ciri yang berbeda, ini disebabkan oleh karena titik tolak keduanya berbeda. Akuntabilitas eksternal didasarkan manajemen hirarkis, sedangkan akuntabilitas internal didasarkan pada tanggung jawab profesional, dengan melekat pada sebuah konsep agen moral (Kande http://e-pendidikan.net/. Diakses Tanggal 20 Oktober 2008).

Karena pendasaran kedua jenis akuntabilitas ini berbeda maka hal-hal yang diperlihatkan pun berbeda. Misalnya, akuntabilitas eksternal memiliki kepercayaan yang rendah, sedangkan pada akuntabilitas internal justru sebaliknya memiliki kepercayaan yang tinggi. Dari segi tanggung jawab, pada akuntabilitas 
eksternal terdapat kontrol yang hirarkis, sedangkan pada akuntabilitas internal tanggung jawab profesional didelegasikan.

Dari segi pelaksanaan tugas, pada akuntabilitas eksternal terikat pada kontrak, sedangkan akuntabilitas internal menekankan pada komitmen, loyalitas, rasa memiliki, dan kecakapan. Akuntabilitas eksternal memperlihatkan proses formal dalam pelaporan dan perekaman untuk manajamen hirarkhis, sedangkan dalam akuntabilitas internal akuntabel banyak konstituen. Dalam akuntabilitas eksternal kurang mengutamakan peran moral, dibanding etika kebiasan, dan etika struktur. Sedangkan jenis akuntabilitas internal, peran moral tinggi sehingga pertimbangannya matang dan memiliki kebebasan untuk bertindak (Kande dalam http:/ /e-pendidikan.net/. Diakses Tanggal 20 Oktober 2008).

Kedua jenis akuntabilitas di atas memiliki pendasaran yang sangat berbeda. Pada akuntabilitas eksternal, pengaruh faktor luar sangat besar, sementara, faktor dalam sangat lemah. Sebaliknya, pada akuntabilitas internal faktor dari dalam diri lebih kuat dibanding faktor luar. Kekuatannya terletak pada motivasi dan komitmen individu untuk melaksanakan akuntabilitas organisasi.

Meminjam analisis Codd tersebut, peneliti memandang bahwa sebenarnya akuntabilitas pengelolaan dana untuk peningkatan mutu pendidikan di Madrasah Aliyah Pesantren Kota Semarang masih dalam tahap akuntabilitas eksternal, yang cenderung bersifat hirarkis. Hal tersebut, di satu sisi dapat dilihat dari fakta bahwa madrasah tersebut menyampaikan laporan hanya sebatas pada pihak struktur yang ada di atasnya. Di sisi lain di bawah atau bahkan yang setara dengannya tidak diberikan laporan.

Madrasah sebagai tempat penyelenggaran manajemen yang akuntabel merupakan suatu pranata sosial. Dikatakan sebagai pranata sosial karena di tempat tersebut terdapat orang-orang dari berbagai latar belakang sosial yang membentuk suatu kesatuan dengan nilai dan budaya tertentu. Nilai-nilai dan budaya tersebut potensial untuk mendukung penyelenggaraan manajemen madrasah yang akuntabel, tetapi juga sebaliknya bisa menjadi penghambat.

Dalam sebuah ilustrasi perusahaan, Robins (2001:14) menegaskan, bahwa keberagaman tenaga kerja mempunyai implikasi penting pada praktik manajemen. Para manajer harus mengubah filosofi mereka dari memperlakukan setiap orang dengan cara yang sama menjadi mengenali perbedaan dan menyikapi mereka yang berbeda dengan cara-cara yang menjamin kesetiaan karyawan dan peningkatan produktivitas, sementara pada saat yang sama, tidak melakukan diskriminasi.

Apa yang dikemukakan Robins berangkat dari asumsi akan perbedaan nilai dan budaya dari setiap anggota organisasi. Ada nilai yang dapat mendukung nilai organisasi, tetapi ada juga yang sebaliknya. Dalam konteks ini, dibutuhkan peran pemimpin untuk dapat mengelolanya.

Bertolak dari ilustrasi di atas, sebenarnya yang menjadi tantangan Madrasah Aliyah Pesantren untuk menegakkan akuntabilitas adalah faktor sistem dan faktor orang. Sistem menyangkut aturan-aturan dan tradisi organisasi. 
Sedangkan faktor orang menyangkut motivasi, persepsi, dan nilai-nilai yang dianutnya. Ketika dikaji lebih jauh, faktor orang sebenarnya tidak berdiri sendiri, melainkan merupakan produk dari masyarakat dengan budaya tertentu.

Tantangan pertama adalah faktor sistem. Sistem pengelolaan dana yang akuntabel untuk meningkatkan mutu pendidikan terdiri atas input, proses, output, dan tujuan. Input pengelolaan dana pendidikan terdiri atas sumber daya manusia, uang, alat dan media, aturan main atau mekanisme, dan lain-lain. Proses pengelolaan dana terdiri dari budgetting, accounting, auditing, sedangkan output pengelolaan dana dalam konteks ini adalah pengelolaan dana yang akuntabel. Sebagaimana dijelaskan sebelumnya bahwa input, proses, dan output pengelolaan dana Madrasah Aliyah Pesantren Kota Semarang belum terstandar dengan baik dan jelas. Hal tersebut misalnya ditandai dengan belum ditegakannya mekanisme pengelolaan yang akuntabel, lemahnya sistem penyusunan RAPBS dan sistem pertanggungjawaban keuangan madrasah. Madrasah Aliyah Pesantren kota Semarang juga belum mengalokasikan dana peningkatan mutu secara cukup.

Secara struktural, madrasah tersebut berada di bawah naungan yayasan, yaitu pesantren. Salah satu komponen penting yang ada pada suatu pesantren adalah kiai. Kiai inilah pada umumnya merupakan "pemilik" pesantren. Meskipun banyak masyarakat yang berpartisipasi dalam pendirian pesantren, namun sebenarnya donator terbesar adalah keluarga besar kiai tersebut, bukan masyarakat. Pihak yang paling berjasa dalam mengumpulkan dana adalah keluarga kiai. Karena ketokohannya itu, banyak pihak, termasuk pemerintah tidak segan dalam memberikan bantuan donasi, maka tidak heran ketika pengelolaan keuangan madrasah di pesantren cenderung tertutup. Semua pemasukan yang diperoleh madrasah langsung disetorkan ke yayasan. Saat uang tersebut dibelanjakan, itu merupakan keputusan yayasan, atau bahkan yang kerap terjadi adalah ketua yayasan itu yang menentukan.

Untuk menegakkan sistem pengelolaan dana yang akuntabel dengan tujuan meningkatkan mutu pendidikan maka pihak madrasah harus memiliki standar pengelolaan yang mencakup standar input, proses, maupun output dalam rangka mencapai tujuan penyelenggaraan pendidikan, yaitu memberikan layanan pendidikan yang bermutu. Dengan demikian, terjadi keselarasan antara upaya peningkatan mutu pendidikan (tujuan) dengan pengelolaan dana yang akuntabel (output). Upaya pembudayaan sistem pengelolaan dana yang akuntabel untuk peningkatan mutu pendidikan tersebut, dapat digambarkan sebagai berikut. 


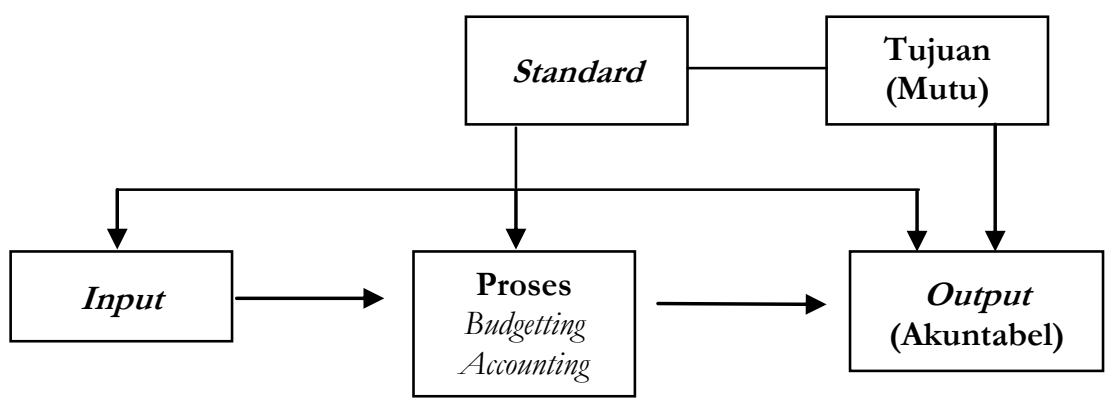

Skema Pembudayaan Sistem pengelolaan Dana Akuntabel

Tantangan kedua adalah faktor orang yang ada di madrasah dan pesantren. Orang merupakan faktor kunci dalam pembudayaan pengelolaan dana yang akuntabel dalam pendidikan. Komitmen, motivasi dan persepsi merupakan sebagian contoh yang dapat membentuk suatu gerakan dan budaya dalam suatu organisasi. Pada hakikatnya, budaya akuntabel sangat ditentukan oleh komitmen dan motivasi orang-orang yang bekerja di dalam organisasi. Komitmen dan motivasi untuk bersikap akuntabel lambat laun akan membentuk budaya dan nilai-nilai yang dianut oleh semua komunitas organisasi, yang dalam hal ini adalah komunitas madrasah. Dalam konteks ini peran penting seorang pemimpin sangat diperhitungkan. Seorang pemimpin dengan keahlian dan pengaruhnya dapat memotivasi dan menumbuhkan komitmen, sehingga kemudian membentuk nilai-nilai dan persepsi bersama komunitas madrasah, yang kemudian semuanya berkontribusi dalam pembentukan budaya akuntabel dalam memberikan layanan pendidikan yang bermutu, terutama masalah pembiayaan dan keuangan madrasah.

\section{SIMPULAN}

Kepala sekolah/madrasah adalah tokoh kunci penyelenggaraan pendidikan. Karena itu, sudah sewajarnya mereka berlaku sebagai pemimpin yang efektif yaitu yang memiliki kemampuan untuk mengatasi suatu masalah termasuk pengelolaan pendanaan. Sebagai akibat dari lingkungan yang berubah dengan cepat, serta dapat mengimplementasikan reformasi yang mengarah pada peningkatan prestasi siswa maka karakteristik pemimpin sekolah/madrasah dituntut untuk membawa madrasah pada perubahan budaya menuju budaya yang akuntabel, termasuk pada aspek pengelolaan dana. Kepala madrasah harus memiliki visi manajerial dan kultural yang akuntabel dalam mengelola dana pendidikan. Visi tersebut kemudian didifusi dan didiseminasi kepada seluruh individu, kelompok dan komponen organisasi di dalam madrasah dalam rangka mencapai pendidikan yang bermutu.

Berdasarkan penelitian diperoleh temuan bahwa pengelolaan dana pendidikan pada Madrasah Aliyah Pesantren Hidayatussubban Semarang, secara 
umum belum akuntabel. Hal tersebut ditandai dengan lemahnya sistem penyusunan RAPBS dan lemahnya sistem evaluasi atau pemeriksaan keuangan, sementara pelaksanaan keuangan pada madrasah tersebut cukup akuntabel. Oleh karena itu, untuk membudayakan pengelolaan dana pendidikan yang akuntabel, pihak madrasah harus mampu menegakkan sistem pengelolaan dana peningkatan mutu pendidikan yang akuntabel terutama melalui kepala madrasah. Sistem pengelolaan dana yang akuntabel untuk meningkatkan mutu pendidikan terdiri atas input, proses, output, dan tujuan. Untuk menghantarkan pada tujuan pendidikan yaitu mutu, diperlukan standar input, standar proses, dan standar output.

\section{DAFTAR PUSTAKA}

Anwar, M.I. 1991. "Biaya Pendidikan dan Metode Penetapan Biaya Pendidikan", Mimbar Pendidikan, No. 1 Tahun X, 28-33; Gaffar, M.F., 1991, “Konsep dan Filosofi Biaya Pendidikan”, Mimbar Pendidikan,, No. 1 Tahun X.

Bastian, Indra. 2006. Akuntansi Pendidikan.Jakarta: Erlangga.

Biro Perencanaan P\&K, 1989.

Creswell, John W. 2008. Educational Research: Planning, Conducting, and Evaluating Quantitative and Qualitative Research. USA: Pearson.

Headington, Rita. 2000. Monitoring, Assesment, Recording, Reporting and Accountability, Meeting the Standards. London: David Fulton Publishers.

Huberman, Michael dan Mattew B. Milles. 1984. Data Management and Analysis Methods. Amerika: New York Press.

Jones, Thomas. 1985. Introduction to School Finance: Technique and School Policy. New York: McMillan Publishing Co.

Kande, Fredrick dalam http://e-pendidikan.net/Diakses Tanggal 20 Oktober 2008

Lembaga Administrasi Negara, 2000, Penyusunan Laporan AKIP. Modul 5, Jakarta: Lembaga Administrasi Negara dan Pengawasan Keuangan dan Pembangunan.

Marsh, Collin. 2008. Becoming Teacher: Knowledge, Skills and Issues. Pearson Prentice Hall: Australia.

Millan, James and. Mcand Sally Schumacher. 2001.Research in Education: A Conceptual Introduction. USA: Longman.

Permendiknas No. 17 dan 19 Tahun 2007

Salleh dan Aslam Iqbal. 1991. Accountability: The Endless Prophecy, Asian and Pasific Development Centre. Kualalumpur Malaysia.

Sallis, Edward. 1993.Total Quality Management in Education.London: Kogan Page.

Slamet P.H. 2005. Handout Kapita Selekta Desentralisasi Pendidikan di Indonesia. Jakarta: Direktorat Pendidikan Lanjutan Pertama, Depdiknas RI.

Tim Dosen UPI. 2009. Administrasi Pendidikan. Bandung:Alfabeta.

Zamroni. 2008. School Based Management. Yogyakarta: Pascarsarjana Universitas Negeri Yogyakarta. 